\title{
The Triassic-Jurassic boundary in the shallow-water marine carbonates from the western Northern Calcareous Alps (Austria)
}

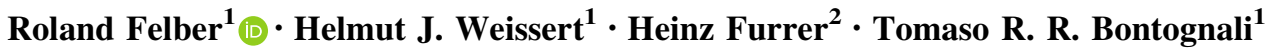

Received: 4 June 2014 / Accepted: 2 June 2015/Published online: 30 July 2015

(C) Swiss Geological Society 2015

\begin{abstract}
The Triassic-Jurassic (T-J) boundary coincides with one of the five biggest mass extinctions in the Phanerozoic. This event has been extensively studied in the eastern and central Northern Calcareous Alps (NCA), where the global stratotype section and point for the base of the Jurassic is outcropping. We present one of the first combined bio-, litho- and carbonate carbon isotope stratigraphic study across the $\mathrm{T}-\mathrm{J}$ boundary from the western NCA, focusing on the shallow-water marine carbonate successions "Lorüns" and "Steinernes Meer". An almost complete T-J succession with the Upper Triassic Kössen Formation, the T-J Schattwald beds and the Lower Jurassic Lorüns oolite is preserved in the Lorüns section, whereas a stratigraphic hiatus at the T-J boundary is observed in the Steinernes Meer section. The carbonate carbon isotope record of Lorüns shows the characteristic $\mathrm{T}-\mathrm{J}$ carbon isotope evolution with a short initial negative carbon isotope excursion (CIE) in the lower Schattwald beds, which is separated from the following and longer main negative CIE in the Lorüns oolite by a positive excursion in the upper Schattwald beds. The synchroneity of the initial and main CIE with the last occurrence of Triassic fauna and the first appearance of Jurassic ammonites suggests placing the T-J boundary at the base of the Lorüns oolite. The Steinernes Meer section records only the main negative CIE in the
\end{abstract}

Editorial handling: W. Winkler and A. G. Milnes.

Roland Felber

roland.felber@gmx.ch

1 Department of Earth Sciences, ETH Zurich, Sonneggstrasse 5, 8092 Zurich, Switzerland

2 Palaeontological Institute and Museum, University of Zurich, Karl-Schmid-Strasse 4, 8006 Zurich, Switzerland
Lorüns oolite due to emersion and/or no sedimentation between the Upper Triassic Kössen Formation and the Lower Jurassic Lorüns oolite, caused by regression and synsedimentary tectonics. This study provides new evidence in support the hypothesis that the latest Rhaetian decrease and the Hettangian recovery of the carbonate production coinciding with the initial and main CIE, respectively, can be interpreted as evidence of acidification of the Tethys ocean due to elevated atmospheric $\mathrm{CO}_{2}$ concentrations, probably caused by voluminous volcanic gas emissions.

Keywords Rhaetian-Hettangian - Tethys ·

Biocalcification crisis - Emersion · Isotope stratigraphy

\section{Introduction}

The Triassic-Jurassic ( $\mathrm{T}-\mathrm{J})$ boundary coincides with one of the five biggest mass extinctions in the Phanerozoic (Hallam and Goodfellow 1990). An U-Pb age of $201 \mathrm{Ma}$ for the boundary has been determined by Schaltegger et al. (2008) and confirmed by Schoene et al. (2010) and Marzoli et al. (2011). The global stratotype section and point (GSSP) for the base of the Jurassic has been defined by the International Subcommission on Jurassic Stratigraphy (Morton 2008) in the Kuhjoch section in the Karwendel Mountains (Northern Calcareous Alps, Austria). Many mechanisms and associated environmental changes have been suggested and animatedly debated to explain the cause of such a dramatic marine and terrestrial extinction (McElwain et al. 1999; Korte and Kozur 2011). Schaltegger et al. (2008) demonstrated that large continental flood basalts of the Central Atlantic Magmatic Province (CAMP) coincide with the $\mathrm{T}-\mathrm{J}$ boundary. Their data 
confirm that volcanism may have triggered the climatic and biotic crisis through voluminous gas emissions (Marzoli et al. 2004; McRoberts et al. 2012; Hautmann 2012). Positive feedback mechanisms like methane release from marine reservoirs could have intensified the potentially devastating effects of widespread eruptions (Marzoli et al. 2004, and references therein). Changes in environmental conditions such as an up to fourfold increase of $\mathrm{pCO}_{2}$ (McElwain et al. 1999), an increase in temperature of 4-8 ${ }^{\circ} \mathrm{C}$ (McElwain et al. 1999; Korte and Kozur 2011) and a sea-level drop (Hallam and Wignall 1999) coincide with the T-J boundary. Although precise cause and effect relationships are still debated, the $\mathrm{T}-\mathrm{J}$ boundary coincides with a major perturbation of the global carbon cycle (McElwain et al. 1999; Ruhl et al. 2011). The sudden addition of massive amounts of isotopically light carbon into oceans and atmosphere is supported by many carbonate and organic carbon isotope records worldwide. It has been shown in sections from St. Audrie's Bay (UK) (Hesselbo et al. 2002), Muller Canyon and Reno Draw (Nevada, USA) (Guex et al. 2004; Ward et al. 2007) and Tiefengraben (Kürschner et al. 2007) and in other sections from the Eiberg basin (Austria) (Ruhl et al. 2009) that the $\mathrm{T}-\mathrm{J}$ boundary is marked by a main negative carbon isotope excursion (CIE), which is separated from the underlying short initial CIE by a positive excursion. The T-J boundary itself is defined by the first occurrence of the Jurassic ammonite Psiloceras spelae tirolicum (Hillebrandt and Krystyn 2009) and is positioned in the main CIE. Although patterns of the carbon isotope record are regionally variable, all of them commonly show one initial negative CIE (McRoberts et al. 1997; Pálfy et al. 2001; Galli et al. 2005; Williford et al. 2007; Crne et al. 2011). The negative CIE is used as global correlation marker for the $\mathrm{T}-\mathrm{J}$ boundary especially in areas where no biostratigraphically useful fossils are found (Galli et al. 2005; Hesselbo et al. 2002). As the GSSP section Kuhjoch in the Eiberg basin and the section Kendlbachgraben belong to the few continuous marine $\mathrm{T}-\mathrm{J}$ successions worldwide, the central and eastern Northern Calcareous Alps (NCA) are in the spotlight for extended research across the $\mathrm{T}-\mathrm{J}$ boundary (McRoberts et al. 2012). On the contrary, the western NCA are poorly studied in this respect. The only published geochemical record was established in a carbonate record from the quarry of Lorüns near Bludenz (McRoberts et al. 1997, 2012). This region shows the marginal facies of the Upper Triassic Kössen basin with erosional unconformities on top of the Rhaetian carbonate platform, followed by shallow water carbonates and hardgrounds deposited on submarine highs and hemipelagic basinal sediments in the Hettangian. The complex palaeogeography in the Early Jurassic is a result of synsedimentary tectonics with formation of horst and graben separated by listric faults (Furrer 1993;
McRoberts et al. 1997). The exact position of the T-J boundary in the western NCA was largely debated because ammonites as the best biostratigraphic markers are rare (Furrer 1993; McRoberts et al. 1997; Furrer and Ortner 2007). This lack of studies reveals the need and importance of more extended geochemical studies across the T-J boundary in the western NCA. The locations Steinernes Meer (or "Auf der Ganda") near Lech and the quarry of Lorüns near Bludenz offer good outcrops for detailed investigations in shallow-water marine carbonate successions. The goal of the present study is (1) to determine the $\mathrm{T}-\mathrm{J}$ boundary in both locations by a combined biostratigraphic and carbonate carbon isotope stratigraphic approach, (2) to test if a proposed drop in sea-level resulted in a sedimentary gap in the studied sections, and (3) to test if the peculiar Lower Jurassic oolite facies observed in the Lorüns section can also be identified in the Steinernes Meer section, and (4) to clarify if the latest Rhaetian decrease and the Hettangian recovery of the carbonate production coincides with the initial and main CIE. Based on these two sections a better tracing of the T-J boundary in the western NCA will simplify further research. Finally, the section located in the western (Steinernes Meer and Lorüns) and central (Eiberg basin) NCA are compared for a correlation with worldwide carbon isotope records across the T-J boundary.

\section{Geological and palaeogeographical setting}

The location Steinernes Meer (or "Auf der Ganda") $\left(\mathrm{N} 47^{\circ} 09^{\prime} 55.0^{\prime \prime} / \mathrm{E} 10^{\circ} 01^{\prime} 23.0^{\prime \prime}\right)$ lies to the west of the village Lech and to the north of the village Dalaas near the Freiburger Hütte. The quarry of Lorüns (N47 $08^{\prime} 12.0^{\prime \prime} /$ E9 $\left.{ }^{\circ} 50^{\prime} 47.0^{\prime \prime}\right)$ is located more to the south-west, near Bludenz (Fig. 1). Both locations belong to the Lechtal nappe of the Bajuvaric nappe group, which represents the lowermost group and most proximal facies belt of the three classical Bavaric, Tirolic and Juvavic nappe stack (Mandl 2000). Consequently, the Upper Triassic to Lower Jurassic sedimentary rocks of the western NCA represent a segment of the extensive carbonate platform along the southern passive margin in the northwestern Tethys (e.g. Berra et al. 2010). In Late Triassic (latest Norian and Rhaetian), the Kössen Formation was deposited above the "PlattenkalkNiveau" (an informal unit in the upper part of the Hauptdolomite Formation) by prograding siliciclastic sedimentation, caused by a global sea level drop and increased precipitation, combined with increasing regional subsidence (Ruhl et al. 2009; Berra et al. 2010). The overlying massive carbonate unit was previously called "Rhätoliaskalk" (Helmcke 1969; Fabricius et al. 1970; Uchdorf 1984). Furrer (1993) introduced the new informal Member 


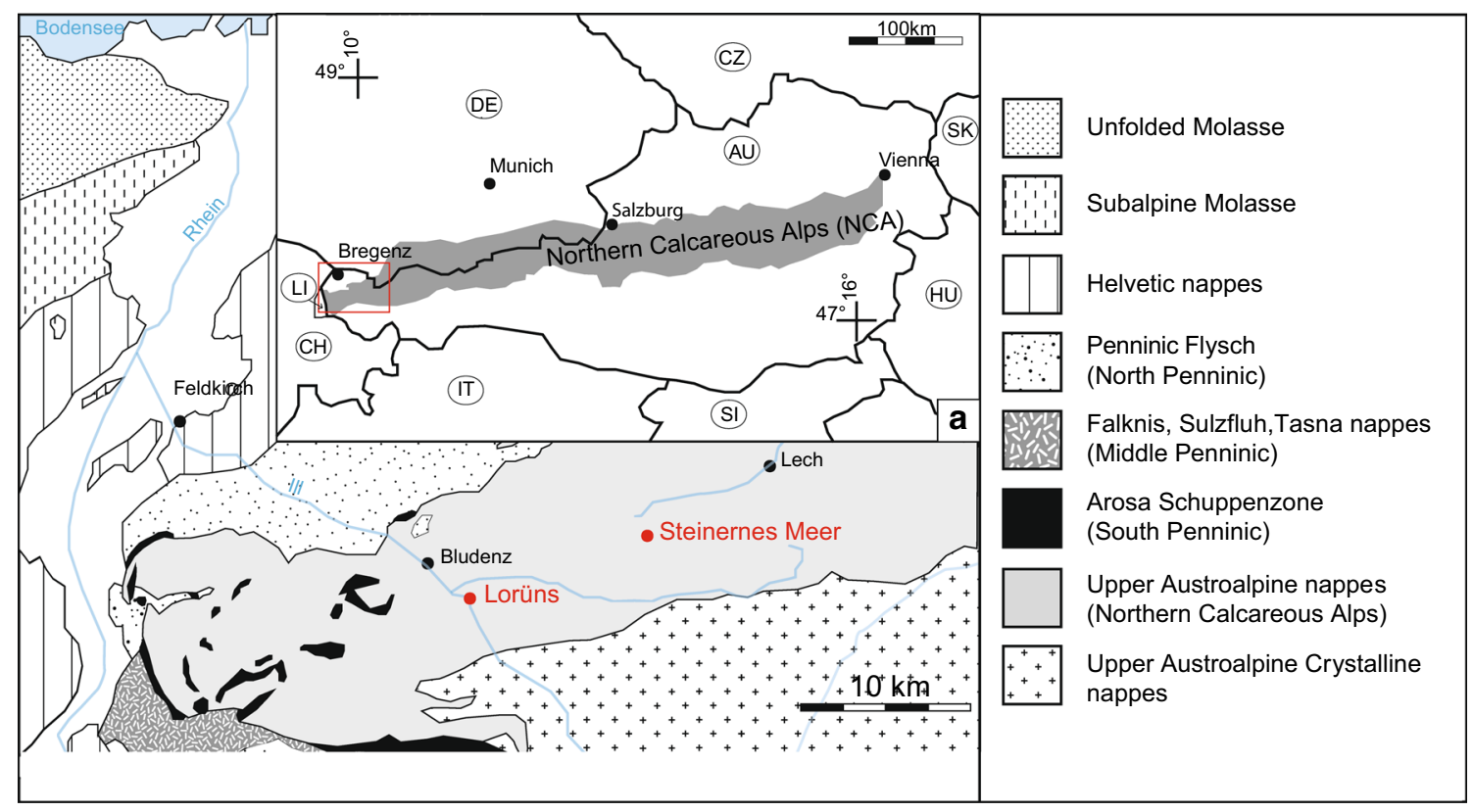

Fig. 1 Geographical and geological overview of the studied sections Steinernes Meer and Lorüns (Vorarlberg, Austria) (after Helmcke 1974)

"Zirmenkopf limestone" in the uppermost part of the Kössen Formation (Rhaetian), the transitional "Schattwald beds" with the supposed T-J boundary and the Hettangian "Lorüns oolite". This succession records the Late Triassic regression and Early Jurassic transgression cycle, whereas the Schattwald beds contain a sequence boundary in between (Hallam 1997; McRoberts et al. 1997). The former "Unterlias-Rotkalk" is an equivalent of the Lower Jurassic Adnet Formation and reflects a deeper and more condensed interval of sedimentation comparable with the Rosso Ammonitico of the Southern Alps (e.g. Kindle 1991). The typical Adnet limestone is of Sinemurian age, but locally starts in Late Hettangian and ends in Early Pliensbachian (Jacobshagen 1965; Tollmann 1976; Furrer 1993). Finally, the Allgäu Formation on top of the succession is dominated by hemipelagic deposits, which are of Sinemurian to Pliensbachian age (Bertle et al. 1979; Kindle 1991).

\section{Methods}

About 300 bulk rock carbonate samples were analysed with a gas chromatograph linked to a continuous flow mass spectrometer in the stable isotope laboratory at the Geological Institute at ETH Zürich. In a first step, all rock samples were cut to have a clean surface. In a second step, they were drilled with a diamond coated micro-drill to obtain fine powder. Between 120-150 $\mu \mathrm{g}$ of each powder sample was weighted into long vials and further flushed with Helium. In a last step, the long vials were put in the gas chromatograph continuous flow mass spectrometer
(MAT 253Thermo-Fischer Finnigan). Carrara marble (MS2) was used as in-house standard. The results are reported in the conventional notation, defined as per mil (\%o) deviation relative to the Vienna Pee Dee Belemnite (VPDB) standard, with machine accuracy in $\delta^{13} \mathrm{C}$ and $\delta^{18} \mathrm{O}$ of better than $\pm 0.1 \%$. Scanning Electron Microscope (SEM) investigations were carried out with a Zeiss supra 50 VP equipped with an EDAX energy dispersive X-ray spectrometer. The analyses were performed on $5 \mathrm{~nm}$ thick platinum or gold-paladium coated thin sections, as well as on unpolished fragments of samples, with a working distance of $7.8-14.4 \mathrm{~mm}$ and an accelerating voltage of $10-15 \mathrm{kV}$. The X-ray powder diffractometer (XRD) was equipped with a Lynxeye superspeed detector at the Geological Institute at ETH Zürich and was performed on two samples. The fine powder of each sample was spread on small plates and fixed with ethanol. The samples were analyzed between $5^{\circ}$ and $90^{\circ}$. The relative amount of dolomite and calcite in the carbonate was identified by comparing the XRD spectrum of the measured sample with known internal standards. The accuracy for the calculated relative amounts of the different components in the samples is better than $10 \%$.

\section{Results}

The bio-, litho- and carbonate carbon isotope stratigraphy of the Steinernes Meer and Lorüns sections are summarized in the Figs. 2 and 3, respectively. The lithologies are classified after the Standard Microfacies Types (SMF) 


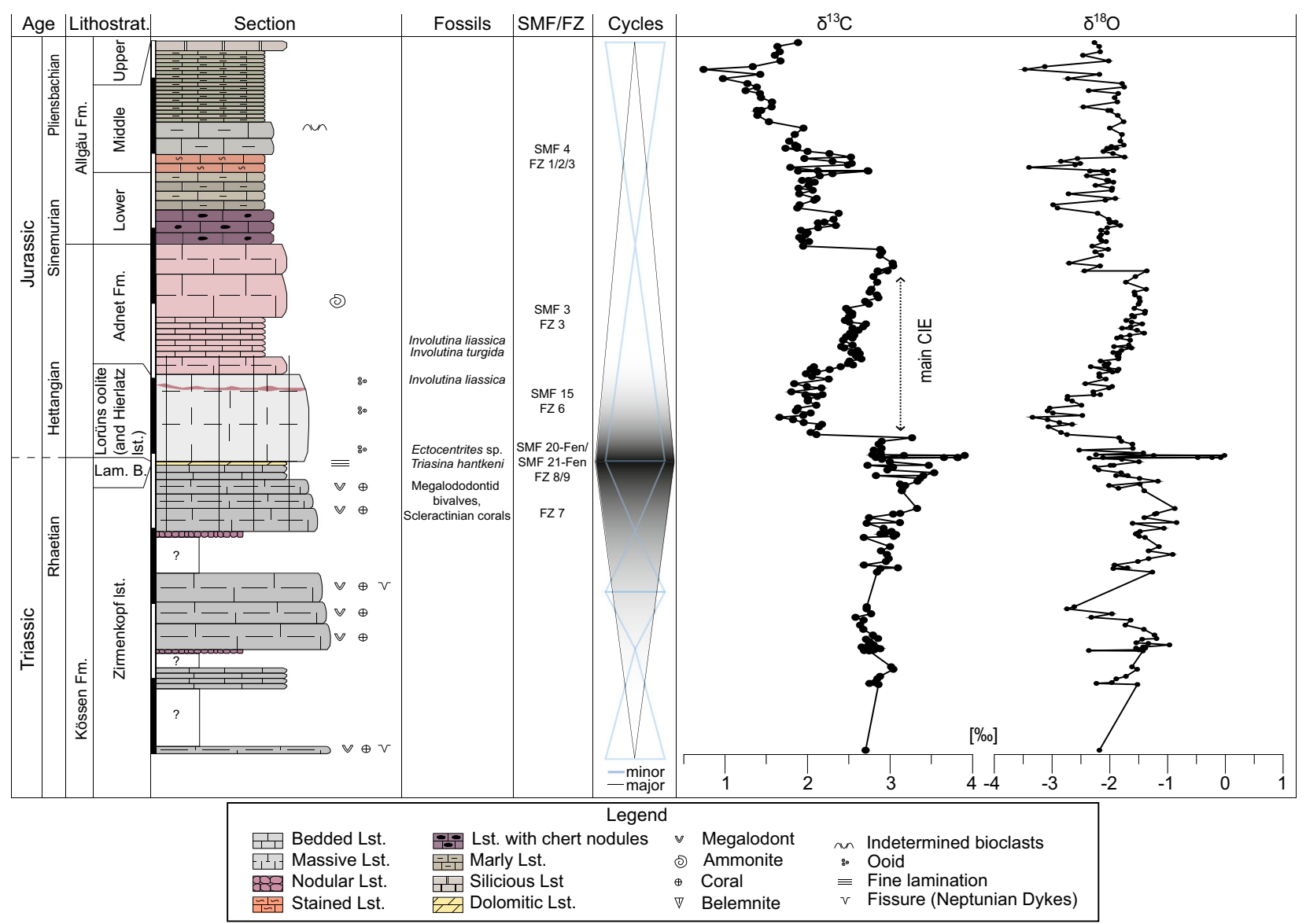

Fig. 2 Summary of the lithostratigraphy, last occurrence of Triassic and first occurrence of Jurassic faunas, Standard Microfacies (SMF) and Facies Zones (FZ), and the carbonate carbon and oxygen isotope

indicating the Standard Facies Zone (FZ) of the modified Wilson model (Flügel and Munnecke 2010). The recent observations are compared and completed with already existing descriptions of other authors (Helmcke 1969; Uchdorf 1984; Furrer 1993).

\subsection{Lithostratigraphy}

The general lithostratigraphic succession at both locations is comparable; both sections include the Zirmenkopf limestone, the Lorüns oolite, the Hierlatz limestone, the Adnet Formation and the Allgäu Formation (Figs. 2, 3). The variations in thickness of the different units (between Steinernes Meer and Lorüns) are remarkable for the Lorüns oolite $(12$ and $22 \mathrm{~m})$, the Hierlatz limestone $(5 \mathrm{~cm}$ and $5 \mathrm{~m})$ and the Adnet Formation (14 and $8 \mathrm{~m}$ ). The red, green, white and black mud- and siltstones, referred to as Schattwald beds (between the Zirmenkopf limestone and the Lorüns oolite in Lorüns) are missing in the Steinernes Meer, where a laminated dolomitic limestone, referred to record of the Steinernes Meer section. The top of the laminated bed (Lam. B.) marks the lowstand between the Late Triassic regression and Early Jurassic transgression. Scale bar $10 \mathrm{~m}$

as laminated bed, marks the top of the Zirmenkopf limestone (Fig. 4). An equivalent bed occurs about $60 \mathrm{~m}$ below the top of the Kössen Formation in Lorüns. The main facies constituting these two beds is characterized by stromatolitic laminations (Fig. 4a), which are likely due to the presence of microbial mats at the time of the formation of the rock. Petrographic analyses of modern stromatolites indicate that similar laminations form through trapping and binding of detrital particles combined with authigenic precipitation of carbonate minerals (Fig. 4b) (Reid et al. 2000; Bontognali et al. 2010). The laminated structure includes large fenestral pores, which have been subsequently filled (likely during a later phase of transgression) with a graded internal micrite and topped by sparitic cement (stromatactis type) (Fig. 4b). The past presence of microbial mats is further supported by SEM investigations, which revealed filamentous structures that may be mineralized remains of extracellular polymeric substances (EPS) (Fig. 4c) (Perri and Tucker 2007; Spadafora et al. 2010). This peculiar bed in the Kössen Formation is interpreted as 


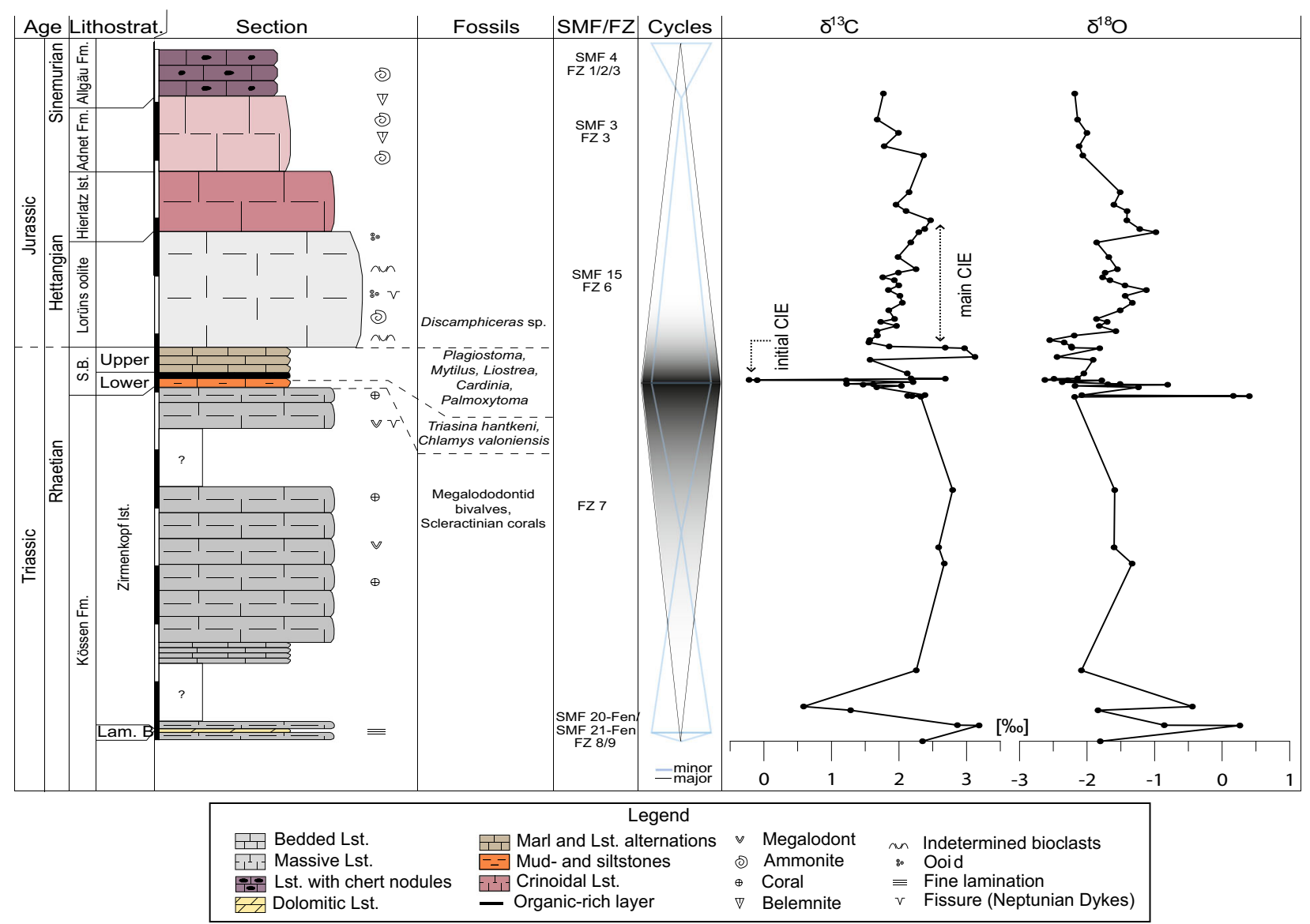

Fig. 3 Summary of the lithostratigraphy, last occurrence of Triassic and first occurrence of Jurassic faunas, Standard Microfacies (SMF) and Facies Zones (FZ), and the carbonate carbon and oxygen isotope record of the Lorüns section. The laminated bed is marked as Lam.

being deposited in the lower intertidal area of a near-coast evaporitic environment. Possible modern analogues for such depositional setting are the coastal sabkhas of the Arabian Gulf, whose intertidal regions are often fully colonized by microbial mats (Alsharhan et al. 2003; Bontognali et al. 2010).

\subsection{Biostratigraphy}

Helmcke (1969, p. 40) found in the Steinernes Meer section one ammonite Ectocentrites sp. about 15-20 m below the base of the reddish limestone ("Unterlias-Rotkalk" or Adnet Formation), evidence for a Late Hettangian age for the upper part of the "Rhätoliaskalk". It is not clear where Helmcke draws the base of the "Unterlias-Rotkalk" and so the stratigraphic position of the ammonite is not known. However, we suppose a position in the Lorüns oolite. A Rhaetian age of the laminated bed (top of the Zirmenkopf limestone) in the Steinernes Meer is suggested by
B. The Schattwald beds (S. B.) mark the sequence boundary between the Rhaetian Kössen Formation and Hettangian Lorüns oolite. Scale bar $10 \mathrm{~m}$

the foraminifera Triasina hantkeni, which indicates a Rhaetian age (Furrer 1993). A Rhaetian age of the Zirmenkopf limestone in the Lorüns quarry is proved by the occurrence of the bivalve Rhaetavicula contorta (Portlock) and the foraminifer Triasina hantkeni MAJZON, both characteristic for the Rhaetian (Furrer 1993; McRoberts et al. 1997). This age is consistent with the occurrence of large megalodontid bivalves and scleractinian corals in the upper part of the Zirmenkopf limestone in both locations. A few specimens of the Rhaetian foraminifer Triasina hantkeni and the bivalve Chlamys valoniensis have been found in the two meter thick sequence of silt- and mudstones of the lower Schattwald beds (boundary beds in McRoberts et al. 1997) in the Lorüns section. The upper Schattwald beds (McRoberts et al. $1997=$ Tiefengraben Member of McRoberts et al. 2012) include Aegerchlamys, Cardinia, Liostrea, Mytilus, Plagiostoma, and Palmoxytoma, which all belong to a transitional Rhaetian-Hettangian bivalve fauna (McRoberts et al. 1997; 2012). Uchdorf 

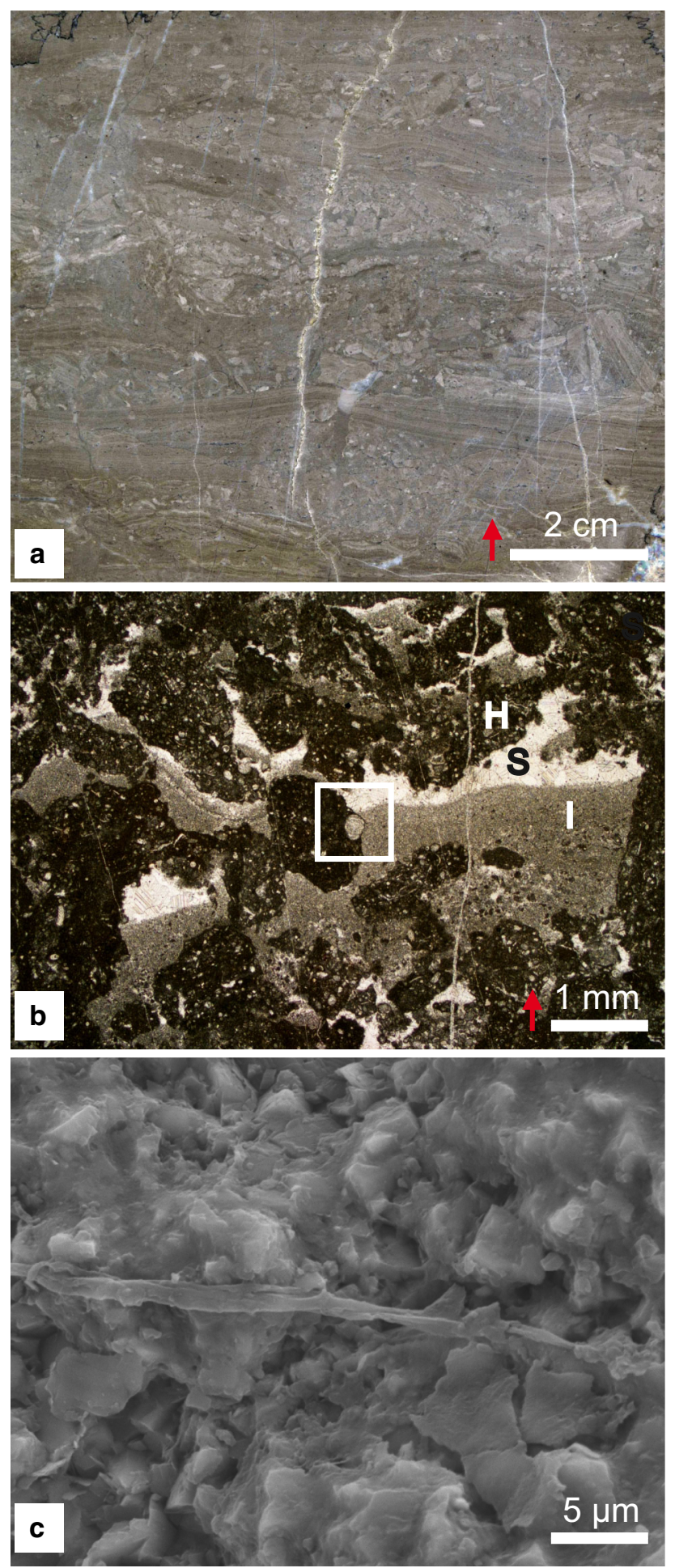

Fig. 4 Macroscopic (a), microscopic (b) and SEM (c) images of the laminated bed. The red arrow marks the younging direction. A foraminifer Triasina hantkeni is marked by the white rectangle just left of a fenestra (stromatactis) in (b). SEM image showing a filamentous structure that may be the mineralized remains of the extracellular polymeric substances that once constituted the microbial mat. (c). $H$ bindstone (host rock), $I$ internal micrite, $S$ sparitic cement
(1984) observed the foraminifer Involutina liassica JONES in the cores of the ooids in the Steinernes Meer, indicating an Early Jurassic age for the Lorün oolite. This is consistent with two ammonites (Discamphiceras sp. and ?Waehneroceras $\mathrm{sp}$.) found in the lower part $(5.5 \mathrm{~m}$ above the base) of the Lorüns oolite of the Lorüns section, which suggest a late Early Hettangian age (Bertle et al. 1979; Furrer 1993; McRoberts et al. 1997).

\subsection{Carbonate carbon and oxygen isotopes}

The carbonate carbon isotope record of Lorüns shows two different negative shifts, one distinct short CIE in the lower Schattwald beds and one less pronounced but longer CIE in the Lorüns oolite. Following the conventional labelling, this succession records the characteristic $\mathrm{T}-\mathrm{J}$ carbon isotope evolution with a short initial negative CIE in the lower Schattwald beds, which is separated from the following and longer main negative CIE in the Lorüns oolite by a positive excursion in the upper Schattwald beds (Hesselbo et al. 2002; Ruhl et al. 2009). The Steinernes Meer section does not record the initial negative $\mathrm{CIE}$, but the main negative CIE within the Lorüns oolite is present. The onset of the main negative CIE differs slightly, starting at the base and within the Lorüns oolite in the sections Lorüns and Steinernes Meer, respectively (Fig. 5). Remarkable are the enriched carbon and oxygen isotope values in the stromatolitic bed in both records, ranging from $2.8-3.9 \%$ and -1.8 to $0.3 \%$, respectively. The broad scatter of the isotopic values are a result of a two-component system (with a $\mathrm{R}^{2}$ of 0.94 in a $\delta^{13} \mathrm{C}$ against $\delta^{18} \mathrm{O}$ crossplot), the bindstone (host rock) and the infilling of the fenestral pores. The enriched values from the bindstone (i.e., the stromatolitic laminae) reflect a highly evaporitic environment, whereas the infilling of the fenestral pores show normal marine values. These values are consistent with the depositional settings proposed above: stromatolites formation in the lower intertidal area of a coastal sabkha environment (e.g., Bontognali et al. 2010) followed by a transgression during which the fenestral pores between the laminations were filled with cement precipitating from seawater.

\section{Discussion}

\subsection{The T-J sections in the western NCA}

The similar lithostratigraphic sections in the locations Steinernes Meer and Lorüns confirm the equivalent palaeogeographic position in the Lechtal nappe as proposed by Jacobshagen (1965). The different thicknesses of 


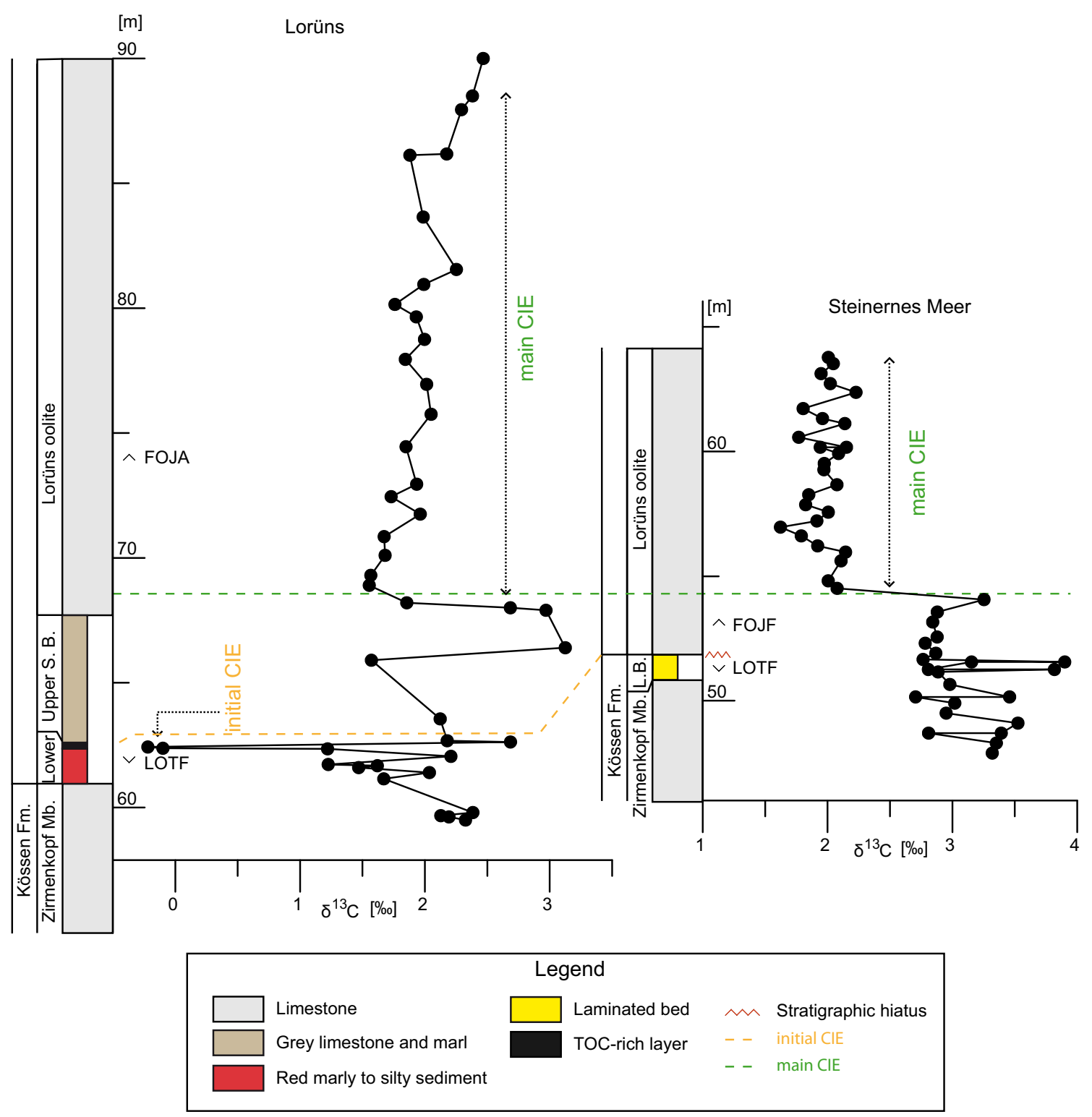

Fig. 5 A comparison of the sections Steinernes Meer and Lorüns. LOTF last occurrence of Triassic fauna, FOJF first occurrence of Jurassic Fauna, FOJA first occurrence of Jurassic ammonoids

the Lorüns oolite, the Hierlatz limestone and the Adnet Formation may be explained with several hypotheses. The thinner Lorüns oolite and Hierlatz limestone and the missing Schattwald beds in the location Steinernes Meer, all suggest a shallow setting including a gap in the sedimentary record due to no sedimentation and/or erosion. The thicker Adnet Formation indicates a more rapid Jurassic deepening of this region. This means that the Steinernes Meer section shows a major cycle of Late Triassic regression and Early Jurassic transgression. The laminated bed within this succession represents the shallowest environment, but besides the fenestral fabrics there are no signs of emersion. A comparable cycle of regression and transgression was proposed by McRoberts et al. (1997) in the Lorüns section, where a possible palaeosoil with extensive mud cracks has been described by Furrer (1993) in the lower Schattwald beds. Another section at the Schesaplana mountain west of Lorüns supports an exposure interval at the T-J transition. There, the upper Schattwald beds rest unconformably on an erosional surface of the Kössen Formation (Furrer 1993; McRoberts et al. 1997). The short initial negative carbonate CIE of $3 \%$ within the Schattwald beds at Lorüns is not present in the Steinernes Meer section. However, the correlation of the Lorüns oolite in the sections Steinernes Meer and Lorüns is supported by the carbonate carbon isotope record, both negative CIEs 
show a similar magnitude and length (Fig. 5). Despite their slightly different starting position, it seems plausible that they record the same geochemical event, conventionally labelled as "longer main CIE" (Hesselbo et al. 2002; Ruhl et al. 2009). Therefore, the T-J boundary is placed between the top of the laminated bed (Kössen Formation) and the base of the Lorüns oolite in the Steinernes Meer section and in the upper Schattwald beds in the Lorüns section.

\subsection{The T-J boundary within the Northern Calcareous Alps}

The Eiberg basin in the central NCA was a large intraplatform trough during the Rhaetian, which can be traced over $200 \mathrm{~km}$ from the Salzkammergut (Austria) in the east to the Lahnenwiesgraben valley (Germany) in the west (Hillebrandt and Krystyn 2009). Several sections (Kuhjoch/Ochsentaljoch, Hochalplgraben, Kendlbachgraben, Restentalgraben, Schlossgraben, Scheibelberg, Kammerköhralm, Eiberg) within the Eiberg basin are correlated by organic carbon isotope stratigraphy (Ruhl et al. 2009). The GSSP section Kuhjoch for the base of the Jurassic in the western Eiberg basin of the Lechtal nappe offers several biostratigraphic and geochemical events for the placement of the T-J boundary: (1) the last occurrence of the Late Triassic ammonoid Choristoceras marshi (and of conodonts), (2) the first occurrence of the ammonite Psiloceras spelae tirolicum, which is the first known Jurassic Psiloceras in Europe, (3) the horizon with the ammonite Psiloceras cf. pacificum, (4) the Calliphyllum bed, (5) the initial negative organic CIE (Hillebrandt et al. 2007; Hillebrandt and Krystyn 2009). Two sections (Kuhjoch, Kendlbachgraben) within the Eiberg basin are shown in Fig. 6 and provide a useful comparison for interpreting our observations because: (1) the Kuhjoch section offers the best comparison as the GSSP for the base of the Jurassic, (2) the Kendlbachgraben section represents a more proximal setting within the Eiberg basin during deposition, (3) the Kendlbachgraben section comprises a carbonate carbon isotope record additionally to the organic carbon isotope record. The lithostratigraphy and the coinciding organic carbon isotope stratigraphy of the two sections differ from each other, which results in different correlations with the sections Lorüns and Steinernes Meer (Fig. 6). The Eiberg Member (Upper Member of the Kössen Formation in the central NCA) in the sections Kuhjoch and Kendlbachgraben consists of limestone and marls and represents the uppermost Rhaetian, characterized by the last occurence of the ammonoid Choristoceras marshi and conodonts in the uppermost beds (Hillebrandt and Krystyn 2009). The Zirmenkopf limestone (Upper Member of the Kössen Formation in the western NCA) is the lithostratigraphic equivalent in the sections Lorüns and Steinernes Meer. In the sections Kendlbachgraben and Kuhjoch, the overlying Tiefengraben Member, a silty to marly sediment, is separated from the Eiberg Member by a few centimeters thick organic-rich layer ( $\mathrm{T}$ bed, Hillebrandt et al. 2007) with an organic carbon content of 5-9\%. A similar organic-rich layer was identified in the lower part of the Schattwald beds in the Lorüns section (organic content of $3 \%$, McRoberts et al. 1997). The Tiefengraben Member in the section Kuhjoch is divided into a lower grey, middle red (referred as Schattwald beds) and upper grey interval with limestone beds. The Schattwald beds are absent in the section Kendlbachgraben. The grey silty to marly interval of the Lower Tiefengraben Member evolves into a limestone interval of the Upper Tiefengraben Member. The grey Upper Tiefengraben Member in the section Kuhjoch shows an increase of intercalated limestone beds towards the Breitenberg Member, similar to the pattern in the section Kendlbachgraben. This interval of the Tiefengraben Member contains the base of the Hettangian (Jurassic) with the first occurrence of the ammonite Psiloceras spelae. The sequence is similar to the upper Schattwald beds in the Lorüns section. Similar carbon isotope evolutions across the T-J boundary are observed in all three sections. The initial negative carbonate and organic CIE in the Lorüns section and the sections Kuhjoch and Kendlbachgraben respectively, always coincides with an organic carbon rich layer. It has been demonstrated that the organic carbon isotope variation is not related to changes in the type of organic matter, but to major changes in the global exchangeable carbon reservoirs (Ruhl et al. 2010). The initial negative CIE at the base of the Tiefengraben Member coincides with the last occurrence of the Late Rhaetian ammonoid Choristoceras marshi and Misikella conodonts at the top of the Eiberg Member (Ruhl et al. 2009). A Late Rhaetian age of the initial negative CIE is supported by the Lorüns section, where below the initial negative CIE the foraminfer Triasina hantkeni and the bivalve Chlamys valoniensis were found, which are characteristic for the Rhaetian (McRoberts et al. 1997).

The main negative CIE starts in the section Kendlbachgraben with the reoccurrence of limestone within the Tiefengraben Member. The main negative CIE in the section Kuhjoch coincides with the base of the grey Upper Tiefengraben Member. This is consistent with Hillebrandt et al. (2007) and Ruhl et al. (2009), who propose that the timing of the reoccurrence of the limestone depends on the depositional setting (i.e., in the more distal Kuhjoch setting, carbonate production and sedimentation was delayed). The main negative CIE in the section Kuhjoch precedes the first occurrence of the ammonite Psiloceras spelae. This implies that the main 


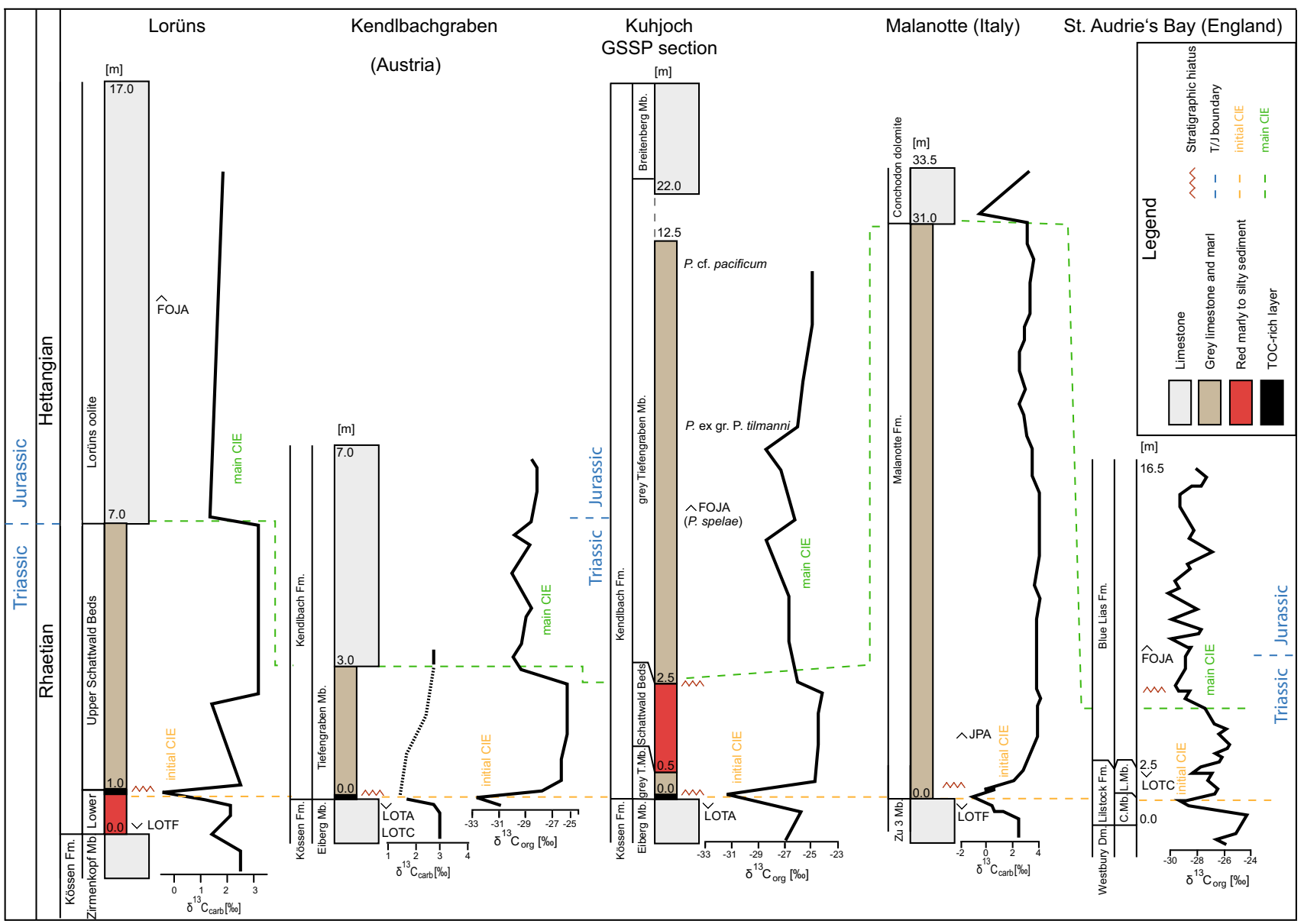

Fig. 6 Correlation of the western (Steinernes Meer, Lorüns) and central Northern Calcareous Alps (Kendlbachgraben, Kuhjoch, Ruhl et al. 2009; Korte et al. 2009;) with sections from Italy (Malanotte, Galli et al. 2005) and England (St. Audrie's Bay, Hesselbo et al.

negative CIE started in the latest Rhaetian and persisted through the T-J boundary until the earliest Hettangian. Unfortunately, no Lower Hettangian ammonites are known from the section Kendlbachgraben. Two psiloceratid ammonites (Discamphiceras sp. and ?Waehneroceras sp.) of late Early Hettangian age were recovered from the Lorüns oolite in the Lorüns section, and a rich psiloceratid ammonite fauna of late Early Hettangian age (e.g. Psiloceras sp. and Waehneroceras $\mathrm{sp}$.) was found in the Schesaplana region at the base of the Adnet Formation overlying the upper Schattwald beds (Furrer 1993). These finds imply that the local onset of carbonate sedimentation in Lorüns is of Early Hettangian age. Based on the correlation of the main negative CIEs, the T-J boundary in the western NCA could be settled in the basal Lorüns oolite. But this interpretation is less favoured than the placement of the T-J boundary at the base of the Lorüns oolite, due to the occurrence of the ammonites (late Early Hettangian) in the Lorüns quarry and the relatively unclear position of the main negative CIE.
2002). LOTF last occurrence of Triassic fauna, LOTA last occurrence of Triassic ammonoids, FOJF first occurrence of Jurassic fauna, FOJA first occurrence of Jurassic ammonoids, JPA Jurassic palynological assemblage

\subsection{Correlation with the Southern Alps and England}

The sections St. Audrie's Bay (United Kingdom, Hesselbo et al. 2002) and Malanotte (Italy, Galli et al. 2005) provide carbon isotope records across the $\mathrm{T}-\mathrm{J}$ boundary that are similar to the records from the NCA (Fig. 6). In the classical marine section of St. Audrie's Bay (UK), the initial negative CIE occurs one meter below the last occurrence of Triassic conodonts and the main negative CIE starts few meters below the first occurrence of the ammonite Psiloceras planorbis (Hesselbo et al. 2002). In the western Southern Alps, Galli et al. (2005) observed a lithostratigraphic $\mathrm{T}-\mathrm{J}$ succession similar to that described in the Lorüns section. A thick bedded limestone with corals and megalodontid bivalves (the Rhaetian Zu3 Member) is separated from an oolithic dolomite or limestone (the Hettangian Conchodon dolomite) by a thinly bedded, micritic limestone with marly to silty beds in between 
(Malanotte Formation) (Galli et al. 2005). These three units are similar to the Rhaetian Zirmenkopf limestone of the Kössen Formation ( $\mathrm{Zu} 3$ Member), the Schattwald beds (Malanotte Formation) and the Hettangian Lorüns oolite (Conchodon dolomite). Galli et al. (2005) recognized a drowning and recovery of the carbonate platform at the first and at a second negative carbonate CIEs, respectively. The first negative CIE coincides with the last occurrence of Triassic fauna and is marked by an iron-rich hardground (Galli et al. 2005). The following positive carbonate CIE within the Malanotte Formation is comparable with the positive carbonate CIE within the upper Schattwald beds in the Lorüns section. The lithological change just below the $\mathrm{T}-\mathrm{J}$ boundary from a carbonate dominated (Zu3 Member and Kössen Formation) to a siliciclastic dominated system (Malanotte Formation and Schattwald beds) reflects a worldwide interruption of the carbonate production, often referred to as biocalcification crisis (Hautmann 2004, 2012; Crne et al. 2011). Proposed cause is a large emission of $\mathrm{CO}_{2}$ related to the Central Atlantic Magmatic Province (CAMP) volcanism, which is supported by an up to fourfold increase of the atmospheric $\mathrm{pCO}_{2}$ across the $\mathrm{T}-\mathrm{J}$ boundary (McElwain et al. 1999). This results in a $\mathrm{CaCO}_{3}$ undersaturation in the seawater and an interruption of carbonate sedimentation (Galli et al. 2005). The second negative CIE in the Malanotte section coinciding with the occurrence of the ooid-bearing Conchodon dolomite is comparable with the main negative CIE at the base of the Lorüns oolite in the sections Lorüns and Steinernes Meer. The appearance of ooid-bearing carbonates is often described as post-extinction lithology (Yin et al. 2007; Brand et al. 2012). Lehrmann et al. (2012) have suggested a combination of mechanisms for the formation of giant ooids in the Precambrian, such as (1) a high carbonate saturation state of the oceans, resulting from reduced skeletal calcium carbonate precipitation, (2) high energy through increased tidal forces and prevalence of ramps and (3) low supply of nuclei for ooid growth due to lack of peloids or skeletal grains. Similar conditions such as an increase in the carbonate saturation state after the biocalcification crisis and high energy due to the transgression could explain the appearance of the Lorüns oolite.

\section{Conclusion}

The aim of the present study was to determine the T-J boundary in the western NCA by a combined bio-, lithoand carbonate carbon isotope stratigraphic approach. Even though both investigated sections were deposited in a similar palaeogeographical position, the Lorüns section shows a more complete $\mathrm{T}-\mathrm{J}$ succession. A big stratigraphic hiatus occurred in the Steinernes Meer section at the top of the Rhaetian Kössen Formation, marked by a laminated bed, and followed by the Hettangian Lorüns oolite. The carbonate carbon isotope record of Lorüns shows the characteristic $\mathrm{T}-\mathrm{J}$ carbon isotope evolution with the initial negative CIE in the lower Schattwald beds, which is separated from the following and longer main negative CIE in the Lorüns oolite by a positive excursion in the upper Schattwald beds. The T-J section Steinernes Meer only records the main negative CIE within the Lorüns oolite. The last occurrence of Triassic fauna and the first appearance of Jurassic ammonites coincide with the initial and main negative CIE, respectively. The T-J boundary of the Steinernes Meer section is placed at the boundary of the Kössen Formation with the Lorüns oolite, suggesting a remarkable hiatus. In the Lorüns section, the hiatus at the $\mathrm{T}-\mathrm{J}$ boundary between the Upper Schattwald beds and the Lorüns oolite is apparently less important. The succession between the Rhaetian Zirmenkopf limestone and the Hettangian Lorüns oolite is marked by a biocalcification crisis as it is known from the Southern Alps and which is reflected by the Schattwald beds in the Lorüns section. In the Steinernes Meer section, the biocalcification crisis is hidden in the stratigraphic hiatus between the laminated bed of the Kössen Formation and the Lorüns oolite. This was driven by emersion of the carbonate platform at the time of a former Rhaetian sea-level drop.

Acknowledgments RF acknowledges financial support provided by Georg Friebe from the inatura Dornbirn foundation and by the Earth Science Department ETH Zurich. Thanks to the Brech- und Siebwerk Lorüns G.m.b.H \& Co. KG for allowing access to the locality.

\section{References}

Alsharhan, A. S., Kendall, C. G., \& St, C. (2003). Holocene coastal carbonates and evaporates of the southern Arabian Gulf and their ancient analogues. Earth-Science Reviews, 61, 191-243.

Berra, F., Jadoul, F., \& Anelli, A. (2010). Environmental control on the end of the Dolomia Principale/Hauptdolomit depositional system in the central Alps: Coupling sea-level and climate changes. Palaeogeography, Palaeoclimatology, Palaeoecology, 290, 138-150.

Bertle, H., Furrer, H., \& Loacker, H. (1979). Geologie des Walgaues und des Montafons mit Berücksichtigung der Hydrogeologie. Jahresberichte und Mitteilungen des Oberrheinischen Geologischen Vereins (N.F.), 61, 101-115.

Bontognali, T. R. R., Vasconcelos, C., Warthmann, R. J., Bernasconi, S. M., Dupraz, C., Strohmenger, C. J., \& McKenzie, J. A. (2010). Dolomite formation within microbial mats in the coastal sabkha of Abu Dhabi (United Arab Emirates). Sedimentology, 57, 824-844.

Brand, U., Posenato, R., Came, R., Affek, H., Angiolini, L., Azmy, K., \& Farabegoli, E. (2012). The end-Permian mass extinction: A rapid volcanic $\mathrm{CO}_{2}$ and $\mathrm{CH}_{4}$-climatic catastrophe. Chemical Geology, 322-323, 121-144.

Črne, A. E., Weissert, H., Goričan, Š., \& Bernasconi, S. M. (2011). A biocalcification crisis at the Triassic-Jurassic boundary recorded 
in the Budva Basin (Dinarides, Montenegro). Geological Society of America Bulletin, 123, 40-50.

Fabricius, F., Friedrichsen, H., \& Jacobshagen, V. (1970). Zur Methodik der Paläotemperatur-Ermittlung in Obertrias und Lias der Alpen und benachbarter Mediterran-Gebiete. Verhandlungen der Geologische Bundesanstalt, 4, 583-593.

Flügel, E., \& Munnecke, A. (2010). Microfacies of carbonate rocks: analysis, interpretation and application (p. 984). Berlin: Springer.

Furrer, H. (1993). Stratigraphie und Fazies der Trias Jura-Grenzschichten in den Oberostalpinen Decken Graubündens. Ph.D. dissertation (p. 112). Zurich: University of Zurich.

Furrer, H., \& Ortner, H. (2007). Nördliche Kalkalpen. In J. G. Friebe (Ed.), Geologie der österreichischen Bundesländer. Vorarlberg (pp. 41-48). Wien: Geologische Bundesanstalt Wien.

Galli, M. T., Jadoul, F., Bernasconi, S. M., \& Weissert, H. (2005). Anomalies in global carbon cycling and extinction at the Triassic/Jurassic boundary: Evidence from a marine C-isotope record. Palaeogeography, Palaeoclimatology, Palaeoecology, 216, 203-214.

Guex, J., Bartolini, A., Atudorei, V., \& Taylor, D. (2004). Highresolution ammonite and carbon isotope stratigraphy across the Triassic/Jurassic boundary at New York Canyon (Nevada). Earth and Planetary Science Letters, 225, 29-41.

Hallam, A. (1997). Estimates of the amount and rate of sea-level change across the Rhaetian-Hettangian and Pliensbachian-Toarcian boundaries (latest Triassic to early Jurassic). Journal of the Geological Society, 154, 773-779.

Hallam, A., \& Goodfellow, W. D. (1990). Facies and geochemical evidence bearing on the end-Triassic disappearance of the alpine reef ecosystem. Historical Biology: An International Journal of Paleobiology, 4, 131-138.

Hallam, A., \& Wignall, P. B. (1999). Mass extinctions and sea-level changes. Earth-Science Reviews, 48, 217-250.

Hautmann, M. (2004). Effect of end-Triassic $\mathrm{CO}_{2}$ maximum on carbonate sedimentation and marine mass extinction. Facies, 50, 257-261.

Hautmann, M. (2012). Extinction: end-Triassic mass extinction. In eLS. Chichester: Wiley. doi:10.1002/9780470015902.a0001655. pub3.

Helmcke, D. (1969). Die Geologie der Spullersee-Mulde zwischen Wildgruben-Roggal-Spitz-Gruppe und Formarin-See in den Vorarlberger Kalkalpen. Ph.D. dissertation (p. 220). Marburg: Philipps-Universität Marburg.

Helmcke, D. (1974). Geologie der südlichen Klostertaler Alpen (Vorarlberg/Österreich). Geologica et Palaeontologica, 8, 131-147.

Hesselbo, S. P., Robinson, S. A., Surlyk, F., \& Piasecki, S. (2002). Terrestrial and marine extinction at the Triassic-Jurassic boundary synchronized with major carbon-cycle perturbation: A link to initiation of massive volcanism? Geology, 30, 251-254.

Hillebrandt, A. V., \& Krystyn, L. (2009). On the oldest Jurassic ammonites of Europe (Northern Calcareous Alps, Austria) and their global significance. Neues Jahrbuch für Geologie und Paläontologie-Abhandlungen, 253, 163-195.

Hillebrandt, A. V., Krystyn, L., \& Kürschner, W. M. (2007). A candidate GSSP for the base of the Jurassic in the Northern Calcareous Alps (Kuhjoch section; Karwendel Mountains, Tyrol, Austria). International Subcommission on Jurassic Stratigraphy Newsletter, 34, 2-20.

Jacobshagen, V. (1965). Die Allgäu-Schichten (Jura-Fleckenmergel) zwischen Wettersteingebirge und Rhein. Jahrbuch der Geologischen Bundesanstalt, 108, 1-114.

Kindle, P. J. (1991). Tektonisch kontrollierte Alterationen und Neubildungen in Prae- und Syn-Rift-Sedimenten der westlichen Nördlichen Kalkalpen. Ph.D. dissertation (p. 178). Zurich: ETH Zurich.
Korte, C., Hesselbo, S. P., Jenkyns, H. C., Rickaby, R. E. M., \& Spötl, C. (2009). Palaeoenvironmental significance of carbon-and oxygen-isotope stratigraphy of marine Triassic-Jurassic boundary sections in SW Britain. Journal of the Geological Society, $166,431-445$.

Korte, C., \& Kozur, H. W. (2011). Bio- and chemostratigraphic assessment of carbon isotope records across the Triassic-Jurassic boundary at Csővár quarry (Hungary) and Kendlbachgraben (Austria) and implications for global correlations. Bulletin of the Geological Society of Denmark, 59, 101-115.

Kürschner, W. M., Bonis, N. R., \& Krystyn, L. (2007). Carbonisotope stratigraphy and palynostratigraphy of the TriassicJurassic transition in the Tiefengraben section-Northern Calcareous Alps (Austria). Palaeogeography, Palaeoclimatology, Palaeoecology, 244, 257-280.

Lehrmann, D. J., Minzoni, M., Li, X., Yu, M., Payne, J. L., Kelley, B. M., et al. (2012). Lower Triassic oolites of the Nanpanjiang Basin, south China: Facies architecture, giant ooids, and diagenesis-Implications for hydrocarbon reservoirs. $A A P G$ bulletin, 96, 1389-1414.

Mandl, G. W. (2000). The Alpine sector of the Tethyan shelfExamples of Triassic to Jurassic sedimentation and deformation from the Northern Calcareous Alps. Mitteilungen der Österreichischen Geologischen Gesellschaft, 92, 61-77.

Marzoli, A., Bertrand, H., Knight, K. B., Cirilli, S., Buratti, N., Verati, C., et al. (2004). Synchrony of the Central Atlantic magmatic province and the Triassic-Jurassic boundary climatic and biotic crisis. Geology, 32, 973-976.

Marzoli, A., Jourdan, F., Puffer, J. H., Cuppone, T., Tanner, L. H., Weems, R. E., et al. (2011). Timing and duration of the Central Atlantic magmatic province in the Newark and Culpeper basins, eastern USA. Lithos, 122, 175-188.

McElwain, J. C., Beerling, D. J., \& Woodward, F. I. (1999). Fossil plants and global warming at the Triassic-Jurassic boundary. Science, 285, 1386-1390.

McRoberts, C. A., Furrer, H., \& Jones, D. S. (1997). Palaeoenvironmental interpretation of a Triassic-Jurassic boundary section from Western Austria based on palaeoecological and geochemical data. Palaeogeography, Palaeoclimatology, Palaeoecology, 136, 79-95.

McRoberts, C. A., Krystyn, L., \& Hautmann, M. (2012). Macrofaunal response to the end-triassic mass-extinction in the West-Tethyan Kössen basin, Austria. Palaios, 27, 607-616.

Morton, N. (2008). Selection and voting procedures for the base Hettangian. Newsletter of the International Subcommission on Jurassic Stratigraphy, 35, 67-74.

Pálfy, J., Demény, A., Haas, J., Hetényi, M., Orchard, M. J., \& Vető, I. (2001). Carbon isotope anomaly and other geochemical changes at the Triassic-Jurassic boundary from a marine section in Hungary. Geology, 29, 1047-1050.

Perri, E., \& Tucker, M. (2007). Bacterial fossils and microbial dolomite in Triassic stromatolites. Geology, 35, 207-210.

Reid, R. P., Visscher, P. T., Decho, A. W., Stolz, J. K., Bebout, B. M., Dupraz, C., et al. (2000). The role of microbes in accretion, lamination and early lithification of modern marine stromatolites. Nature, 406, 989-992.

Ruhl, M., Bonis, N. R., Reichart, J. S., Damsté, J. S. S., \& Kürschner, W. M. (2011). Atmospheric carbon injection linked to endTriassic mass extinction. Science, 333, 430-433.

Ruhl, M., Kürschner, W. M., \& Krystyn, L. (2009). Triassic-Jurassic organic carbon isotope stratigraphy of key sections in the western Tethys realm (Austria). Earth and Planetary Science Letters, 228, 169-187.

Ruhl, M., Veld, H., \& Kürschner, W. M. (2010). Sedimentary organic matter characterization of the Triassic-Jurassic boundary GSSP at Kuhjoch (Austria). Earth and Planetary Science Letters, 292, $17-26$. 
Schaltegger, U., Guex, J., Bartolini, A., Schoene, B., \& Ovtcharova, M. (2008). Precise U-Pb age constraints for end-Triassic mass extinction, its correlation to volcanism and Hettangian postextinction recovery. Earth and Planetary Science Letters, 267, 266-275.

Schoene, B., Guex, J., Bartolini, A., Schaltegger, U., \& Blackburn, T. J. (2010). Correlating the end-Triassic mass exctinction and flood basalt volcanism at the $100 \mathrm{ka}$ level. Geology, 38, 387-390.

Spadafora, A., Perri, E., McKenzie, J. A., \& Vasconcelos, C. (2010). Microbial biomineralization processes forming modern Ca: $\mathrm{Mg}$ carbonate stromatolites. Sedimentology, 57, 27-40.

Tollmann, A. (1976). Analyse des klassischen Nordalpinen Mesozoikums: Stratigraphie, Fazies und Fauna der nördlichen Kalkalpen (p. 580). Wien: Franz Deuticke.

Uchdorf, B. (1984). Das Rhät in den Vorarlberger Kalkalpen (Österreich) : Fazies und Paläogeographie. Ph.D. dissertation (p. 91). Berlin: Freie Universität Berlin.
Ward, P. D., Garrison, G. H., Williford, K. H., Kring, D. A., Goodwin, D., Beattie, M. J., \& McRoberts, C. A. (2007). The organic carbon isotopic and paleontological record across the Triassic-Jurassic boundary at the candidate GSSP section at Ferguson Hill, Muller Canyon, Nevada, USA. Palaeogeography, Palaeoclimatology, Palaeoecology, 244, 281-289.

Williford, K. H., Ward, P. D., Garrison, G. H., \& Buick, R. (2007). An extended organic carbon-isotope record across the TriassicJurassic boundary in the Queen Charlotte Islands, British Columbia, Canada. Palaeogeography, Palaeoclimatology, Palaeoecology, 244, 290-296.

Yin, H., Feng, Q., Lai, X., Baud, A., \& Tong, J. (2007). The protracted Permo-Triassic crisis and multi-episode extinction around the Permian-Triassic boundary. Global and Planetary Change, 55, 1-20. 